\title{
Social Security and Minority Economic Development
}

\author{
Wei Zheng \\ Political Science and Law Institute, Shihezi University \\ E-mail: zhwsunnyshine@sina.com
}

\begin{abstract}
For the thirty years of the implementation of reform and opening up policy, China has made significant achievements in the economic development. And the western region resided by the minorities has also made great progress in the economic growth. However, there is still a great gap compared with the well-developed eastern coastal region. Relatively speaking, the economic development of western region is still backward. People have lower ability of self-protection and the family security and they have stronger desire for social security. Social security, as the means and mechanism to promote economic development and safeguard the social stability, plays an important part in the economic system of the minorities. Under the circumstances that the economy in minority areas needs to be improved urgently, the interaction will become more significant of the social security and economic development of the minorities.
\end{abstract}

Keywords: Minority economy, Social security, Supply and demand, Social fairness

\section{Social security plays an important role in the minority areas.}

The western part of China, with the area of about 5,400,000 square kilometers, accounting for 57\% of total Chinese land area, is resided by the minorities. It is abundant in natural resources and has great market potentials. However, due to various reasons, the western region is relatively backward in economic development. By now, though reform and opening-up has been carried out for almost thirty years, there are gaps between the east and the west in many aspects. This situation does not only restrict the economic development of the western region, but also induces a series of social problems, and some unrest and turbulence in some places.

To achieve the objective of constructing a comprehensive well-off society, the low level social security in western region must be improved. Take Xinjiang Uygur Autonomous Region as an example. According to statistics of 2002, workers of Xinjiang participating in old-age insurance, medical insurance, unemployment insurance, were 1,155,000 persons, 1,481,000 persons, 1,312,900 persons respectively, only accounting for $47.68 \%, 61.13 \%, 54.19 \%$ of the total workers of that year. Workers of Xinjiang Production and Construction Corps participating in old-age insurance, medical insurance, unemployment insurance, were $669500,875700,538800$, only accounting for $70.10 \%, 91.69 \%$, $56.41 \%$ of the total number of employees in that year.

It is no doubt that social security is of great importance in the minority areas. However, the gap between the east and the west in development is increasingly getting big, which results in the gap of the social security between eastern and western parts of China. In the western area on which the poverty-stricken population dwells, the level of social security is low and problems of shortage of food and clothing are still need to be settled. The establishment of social security system in the western region is to meet the strategic demand of developing the talents, and is one of the fundamental requirements of keeping the local talents, attracting more talents from other places and solving the problem of brain drain. Social security is composed by social insurance, social relief, social welfare, and social allowances, etc. It is the vital part of market economy system. It can promote the social stability, regulate the economic growth, maintain the social fairness, provide basic security for the people with living difficulty, improve the social welfare and the level of society as a whole through the distribution and redistribution. The above functioning in the western minority areas plays a vital role in maintaining and promoting the social fairness, and effectively regulating the local economic growth.

\section{Social security works to solve the problem of poverty in minority areas.}

The population in western region accounts for $29.1 \%$ of the total Chinese, but the extent of poverty is high. The "Eight and Seven National Anti-Poverty Program" lists 592 counties of poverty, among which there are 258 autonomous counties of minorities and 224 counties are located in the western region, accounting for $86.8 \%$ of the total 
poverty-stricken counties of the minorities. By the end of 2006, in the western region, rural people of absolute poverty (with annual per capita income no more than 693 yuan) are 11,750,000, accounting for $54.7 \%$ of the total Chinese population of absolute poverty. There are 19.86 million people with low income in rural area (with per capita annual income no more than 958 yuan), accounting for $55.9 \%$ of the overall Chinese counterparts. Governments should put it in the extremely important position solving the poverty problem, provide the local people with material interests and social welfare to win the recognition and support from the local people and the agreement of the existing local systems. Governments in the western region must continue to develop the economy through innovation to get rid of poverty and win the strong support from the local people and get higher authority.

One of the reasons of poverty is the inequitable distribution of wealth. Although it is a means of social development for a few people to get rich first and then lead majorities of people to get rich. However, in the process, polarization will inevitably turn up and the problem of poverty appears. Social security can regulate the inter-generational income redistribution and intra-generational income redistribution, income redistribution among the same generation and the redistribution of national income as well, thus affecting social reproduction, and reducing the inequality of wealth distribution. Social relief, as an integral part of social security, is one of the ways to solve the problem of poverty. Social relief means that the state and society offer the life security and assistance of material or money to those vulnerable groups of the poor and unfortunate people.

Social relief is the last security backing so that members of society can receive the most basic assistance to maintain their basic living when they have no source of income or are in great poverty. The premise that some people get rich before they lead the others to be rich is that they can not make the others get poorer. There is a great wealth disparity between east and west in China. Resources in all aspects are unevenly distributed. But social security can through redistribution give the needy the basic necessities for living, and make the relatively backward western areas enjoy the great achievements of economic development brought about by reform and opening up.

\section{Social security can promote economic development in minority areas by regulating the supply and demand.}

British economist John Maynard Cairns pointed out that the employment relies on the effective demand, which depends on the tendency of investment and the temptation of consumption. Relative surplus of capital and unemployment is due to insufficient effective demand. Only by the "invisible hand" (the market self-regulation), public resources can not be fully used to achieve full employment. It is necessary for the governments to adopt fiscal policy, welfare policy and other macro-economic policies, to increase national investment and national consumption, enhance social consumption tendency and investment to achieve the purpose of expanding the effective demand of society and promoting full employment and inhibiting the economic crises.

Social security, by regulating the changes of security, the revenue and expenditure of social security fund, realizes its effects on social aggregate supply and aggregate demand, thus effectively contributing to sustained and healthy development of the social economy. Early in the last century, there appeared a serious economic crisis in Western countries. Cairns believes that the absence of effective demand is the main reason for the economic crisis. One of the effective ways is to stimulate effective demand to get rid of it. Today, for the global economic crisis caused by the credit crisis in the United States, governments all over the world, adopting the same measures, put stimulating social effective demand in an important position. And the economic adjustment of social security is also visible. In the period of cold economy when economy grows slowly and workers decrease their income, social security fund has greater expenditure than the revenue, which relatively increases the monetary income of every family. Consumers enhance the relative purchasing power. Aggregate demand goes up. All helps to restore the economic growth and get out of the economic recession. In the period of overheated economy when economy accelerates its growth and workers increase their income, social security fund has more income than the expenditure, which relatively decreases the monetary income of families. Consumers have relatively low purchasing power, which reduces the aggregate demand of the whole society, thereby inhibiting the over-heated growth of the economy.

Economy in western region of the minority areas develops slowly. An important reason of less attraction to investment from the other well-known enterprises is the absence of effective demand. In 2005, the economic growth rate of western region reached 12.7 percent, with GDP of 3339 billion yuan, accounting for $17.0 \%$ of the national total GDP. However, the final consumption rate of the western region only accounts for $30 \%$ more. In 2005 , the 12 provinces of western region realized the total retail sales of social consumer goods of 1158.1 billion yuan with the growth rate of only $14.0 \%$. The low level of consumption in western minority areas can not have strong attraction to the investment from the strong companies in the eastern coastal region and foreign multinational enterprises, which results in few high-quality businesses, few jobs, and slow income increase. Therefore, enlarging the investment to the social security in minority region and improving the living standards of local people are positive and effective to expand the local effective demand and increase consumption, and promote the economic development. 


\section{Social security promotes the shaping of sound social and economic environment in minority areas.}

For the minority areas in the context of West Development, the sound market and social environment is particularly important for economic growth. If social environment is unstable, socio-economic development would be difficult. Due to various reasons, some disturbing factors and social issues are relatively easy to emerge in the western minority areas, which is detrimental to the healthy economic development in the local places. Thus social security functions evidently in maintaining fairness and promoting social stability. With the continuous improvement and development of market economy, social members have differences in their own qualities, labor capacities and abilities of the competitiveness. The difference in economic income will inevitably lead to the gap of their living standards, or result in social conflicts. Social security pools the fund through taxes and compulsory insurance. Governments redistribute the social wealth and offer appropriate assistance to the vulnerable groups in the social competition, which safeguards the basic livelihood of citizens, enhances their physiological and safety security, and to some extent, maintains the social justice, promotes social stability, and provides an important condition to create a good social environment.

Social security can also provide a very good economic environment for the healthy growth of market economy in the western minority region with its abilities of regulating economy. Capital and labor are the two decisive factors in the economic growth. Savings and investment of social security fund can be turned into capital accumulation to increase the capital reserve of the community as a whole in order to protect the economic development. As for the labor in the western region, social security can raise the level of health care and unemployment insurance, etc., improve the basic living standards of ordinary people, enhance the quality of the labor force, protect the reproduction of labor force and extend the average working life of workers, and further increase the total labor volume. Through the interaction of capital and labor, social security system can effectively promote the economic growth and maintain the good economic environment.

As far as the western minority region is concerned, a good social environment is urgent and necessary to the economic development. Meanwhile, a good economic environment will promote the stable development of the social environment. The establishment and betterment of the social security system in minority areas will undoubtedly promote the sound development of the local social and economic environment.

\section{Concluding remarks}

Social security has played a positive role in promoting the economic development and is of great significance for the economic reform and development in the western minority areas. In 2008, the global economic crisis resulting from the sub-loan crisis in the United States shows that market economy is not a panacea but has some defects in some respects. Therefore, to make the socialist market economic system run and develop well, it becomes necessary to establish and improve the corresponding social security system, to redistribute social wealth through government and public organizations. With the development of the market economy in the western region and the increasing advanced social productive forces, social security objects should be expanded from urban workers to rural residents as well as all members of society. Social security system in the western region should be further improved to meet the demand of the economic development.

In short, good economic run needs a good market environment. What the western region now needs greatly is a good market environment. And a stable and effective social security policy functions positively and significantly in maintaining the social stability, improving the social and economic environment in the western region, thus effectively promoting the economic development of the minorities.

\section{References}

Cairns, John Maynard. (1999). Theory of employment, interest and money. The Commercial Press.

Fang, Shiyu. (2006). Promotion and hindrance: dual effects of social security on the economic development. China securities and futures. Vol. 8.

Li, Zhen. (2001.12). Theory of social security. China Labor and Social Security Publishing House.

Liu, Yongji. (2007.09). National economics. China Economy Publishing House.

Ma, Dongmei and Liang, Yong. (2004). The social security system and Chinese economic development. Journal of Guangdong College of Finance, Vol 3.2.

Report on the economic development in Western China. (2005).

Zhang, Liyan. (1995). Talking about the function and influences of social security system on developing market economy. Theory Exploration, Vol. 5.

Zheng, Gongcheng. (2001). Trying a consensus in the differences: economic perspective of social security. Economic and Management Research.

Zheng, Gongcheng. (2003). China's social security reform and institution construction. Journal of Remin University of China, Vol. 1.

Zhong, Renyao. (2005). Social assistance and social welfare. Shanghai University of Finance and Economics Press. 